\title{
Cork - a renewable raw material: forecast of industrial potential and development priorities
}

\section{Ana Paula Duarte* and João Carlos Bordado}

Departamento de Engenharia Química, Instituto de Biotecnologia e Bioengenharia, Instituto Superior Técnico, Lisboa, Portugal

\section{Edited by:}

Guilherme Mariz De Oliveira Barra,

Federal University of Santa Catarina,

Brazil

\section{Reviewed by:}

Chung Hae Park, Ecole Nationale

Supérieure des Mines de Douai,

France

Claudia Merlini, Federal University of

Santa Catarina, Brazil

\section{*Correspondence:}

Ana Paula Duarte, Departamento de Engenharia Química, Instituto de

Biotecnologia e Bioengenharia,

Instituto Superior Técnico, Av. Rovisco

Pais, Gabinete 5-1.10, Torre Sul,

Lisboa 1049-001, Portugal

e-mail: anapduarte@tecnico.

ulisboa.pt
This article aims to report the main applications of cork material from ancient times until nowadays, describing its industrial potential for other applications under study. It is also described the cork origin, the extraction process, and the relationship between composition and cellular structure with properties.

Keywords: cork, structure, properties, main applications, emergent application, environmental impact

\section{INTRODUCTION}

Cork is a natural material used by man for over 5000 years. In China, Egypt, Babylon, and Persia for about 3000 B.C., cork was already used for sealing containers, fishing equipment, and domestic applications and in ancient Greece (1600 a 1100 years B.C.) cork was used in the footwear, to manufacture a type of sandals attached to the foot by straps, generally leather and with a sole in cork or leather (Cork Information Bureau, 2010; Mourão et al., 2011; Cortiça). In the second century A.C., a Greek physician, Dioscorides, noted several medical applications of cork, mainly for hair loss treatment (Cork Information Bureau, 2010). Nowadays, the majority of people know cork for its use as stoppers in wine bottles. The introduction of cork stoppers occurred in the beginning of the seventeenth century by the Benedictine monk Dom Pérignon, to seal the bottles of his famous champagne, Dom Pérignon. In 1729, cork stoppers were adopted by Ruinart and in 1973 by Moet et Chandon, that uses it until nowadays (Cork: a versatile material employed in many different sectors; Cortiça).

Cork is a material obtained from the bark of a tree, the Cork Oak (Quercus suber $L$.), or more exactly from the outside layer of the trunk of the trees, from which is periodically removed without harming the tree, usually every 9-12 years (depending on the culture region), to assure the cork layer reached the minimum required thickness (Cork: a versatile material employed in many different sectors; Silva et al., 2005). The cork oak must be about 20-25 years old before its bark, called "virgin cork," is removed for the first time; a second extraction of the cork is called "secundeira" (The many uses of cork). Only cork obtained from the third stripping, called "amadia" is suitable for manufacture stoppers (Cortiça); however, the first "amadia" cork is still very porous and irregular. In the same tree, the quality improves along the time.
Quercus suber L. is a slow growing, evergreen oak that flourishes only in specific regions of the Western Mediterranean (Portugal, Spain, Southern France, part of Italy, North Africa) and China (Gil, 1998; Costa et al., 2003; Silva et al., 2005) because it requires a great deal of sunlight and a highly unusual combination of low rainfall and somewhat high relative humidity. Europe produces more than $80 \%$ of the world's cork, being Portugal the major cork producer (Barberis et al., 2003; Silva et al., 2005).

Cork composition varies depending on geographic origin, climate and soil conditions, genetic origin, tree dimensions, age (virgin or reproduction), and growth conditions. However, in general, cork is composed by suberin (average of about $40 \%$ ), lignin (22\%), polysaccharides (cellulose and hemicellulose) (18\%), extractables $(15 \%)$ and others (Cork: a versatile material employed in many different sectors; Pereira, 1979, 1982, 1988; Bento et al., 1992; Cordeiro et al., 1995; Bernards and Lewis, 1998). The chemical structure of cork, covering its main components is analyzed in detail in Silva et al. (2005).

Cork presents a characteristic cellular structure in which the cells have usually a pentagonal or hexagonal shape (Figure 1). The cellular wall consists of a thin, lignin rich middle lamella (internal primary wall), a thick secondary wall made up from alternating suberin and wax lamella and a thin tertiary wall of polysaccharides. Some studies suggest that the secondary wall is lignified, and therefore, may not consist exclusively of suberin and waxes (Bento et al., 1992). The cells of cork are filled with a gas mixture similar to the air, making them behave as authentic "pads," which contributes to the capability of cork recover after compressed (Cortiça).

The high concentration of suberin in cork is responsible for many of cork's properties, such as high elasticity and low permeability. These properties together with the resistance to 
A

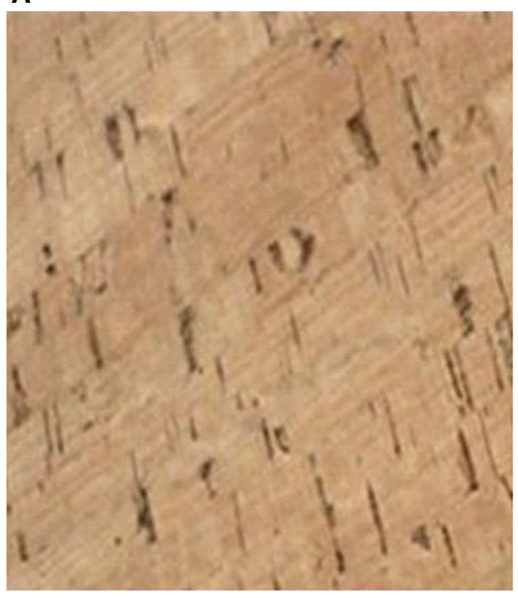

B

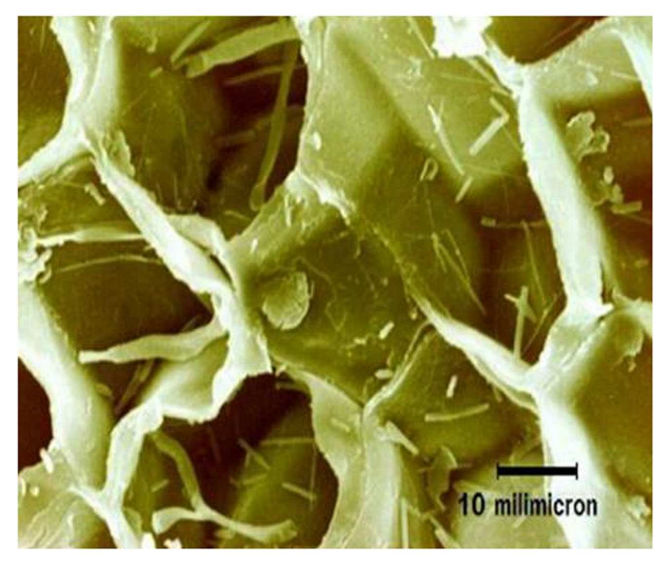

FIGURE 1 | (A) Visual appearance of natural cork; (B) cellular structure of cork observed at SEM (Cortiça).

Table 1 | General properties of cork.

Value

References

\title{
General properties
}

Friction coefficient (cork/cork), boiled

Density $\left(\mathrm{Kg} / \mathrm{m}^{3}\right)$

Thermal conductivity $(\mathrm{W} / \mathrm{m} . \mathrm{K})$

Electrical conductivity $(\mathrm{S} / \mathrm{m})$

Acoustic resistivity $\left(\mathrm{Kg} / \mathrm{m}^{2} . \mathrm{s}\right)$

Specific heat (J/Kg.K)

Thermal diffusivity $\left(\mathrm{m}^{2} / \mathrm{s}\right)$

$\begin{array}{lll}0.97 \text { (radial direction) } & & 0.77 \text { (non-radial directions) } \\ 120-180 \text { (amadia) } & & 160-240 \text { (virgin) } \\ & 0.045 & \\ 1.2 \times 10^{-10}\left(25^{\circ} \mathrm{C}\right) & & 1.67 \times 10^{-13}\left(50^{\circ} \mathrm{C}\right) \\ & 1.2 \times 10^{5} & \\ & 350 \\ & 1.0 \times 10^{-6}\end{array}$

Vaz and Fortes (1998)

Fortes and Rosa (1988)

Gil (1998)

Fortes and Nogueira (1989)

Medeiros (1945)

Gil (1998)

Gil (1998)

\section{Table 2 | Mechanical properties of cork.}

\section{Value}

References

\section{Radial direction Non-radial directions}

\section{Mechanical properties}

Compressive modulus, unboiled (MPa)

$\begin{array}{cc}8-20 & 13-15 \\ 6 & 8-9 \\ 11 & 11 \\ 15 & 14 \\ 38 & 24-26 \\ 0.75-0.80 & 0.6-0.7 \\ 4 & 6 \\ 1 & 1.1 \\ 5 & 9\end{array}$

\author{
Rosa et al. (1990), Rosa and Pereira (1994), \\ Vaz and Fortes (1998) \\ Rosa et al. (1990) \\ Rosa and Pereira (1994) \\ Rosa and Pereira (1994) \\ Rosa and Fortes (1991) \\ Gibson et al. (1981), Vaz and Fortes (1998) \\ Gibson et al. (1981) \\ Gibson et al. (1981) \\ Gibson et al. (1981)
}

Compressive modulus, boiled (MPa)

Compressive modulus, heat treated at $150^{\circ} \mathrm{C}, 28$ days (MPa)

Tensile modulus, boiled (MPa)

Collapse (bucking) strain (\%)

Fracture stress under tension (MPa)

Fracture strain under tension (\%) deterioration and the nearly odorless and tasteless, makes cork very suitable to be used as bottle stoppers (Cork: a versatile material employed in many different sectors; The many uses of cork; Silva et al., 2005).

In addition to the referred properties, cork is further characterized by low density, good resistance to fatigue, low thermal conductivity (it is an excellent thermal insulator), low speed of sound propagation and low acoustic impedance (it is an excellent sound insulator), high resistant to combustion (serves as the progression of fire retardant), good wear resistance, and hypo-allergenicity (since not absorb dust, not cause allergies) (Cortiça). In Tables 1 and $\mathbf{2}$ are presented 
quantitatively, the general and the mechanical properties of cork, respectively.

The unique combination of properties presented by cork contributes for its use in a wide range of applications. Since the early twentieth century, cork had a massive expansion, mainly resulting from the development of cork-based agglomerates (Gil, 2014).

\section{COMPARISON WITH OTHER FOAMED MATERIALS}

Polyurethane- (PU) and polyethylene (PE)-based foams can present a vast range of properties when compared with cork; however, due to its defined morphology and structure, this one presents a limited range of variation in properties and for this reason can compete with synthetic foams in specific application.

Despite cork presents poor mechanical properties when compared with foams with rigid cell walls, such as metals and ceramics that present more resistance to mechanical loads and higher stiffness, its cells are strong and the specific strength is as good as any rigid synthetic foam. Thus, and concerning mechanical properties, cork is similar to flexible polymer foams (Gibson and Ashby, 1997; Silva et al., 2005). A quantitative comparison between the mechanical properties of cork and others foamed materials are presented in Figure 2, while a similar comparison, but considering the thermal conductivity, is presented in Figure 3.

The good damping properties of cork make it appropriate for load-bearing applications, acting as filler in other plastics and elastomers formulations.

The low thermal conductivity and the reasonable compressive strength make cork an excellent material for thermal insulation where compressive loads are present, even when compared with other foamed materials (Gibson and Ashby, 1997; Silva et al., 2005).

\section{MAIN APPLICATIONS OF CORK}

The relevant properties presented by cork coupled with the fact that it is a natural, renewable, and recyclable material makes it

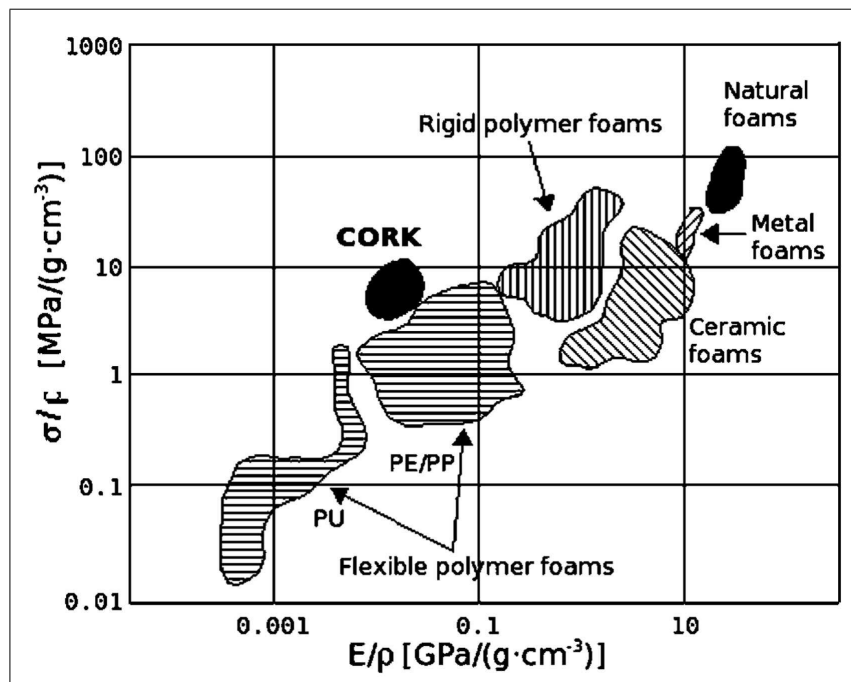

FIGURE 2 | Comparison between specific compressive strength $(\sigma / \rho)$ and specific modulus $(E / \rho)$ for cork and different foamed materials (Silva et al., 2005). appropriate for a variety of applications. Most of the cork, around $70 \%$, is used as bottle stoppers; however, this material is also largely used for the production of cork-based composites employed for different technological applications, such as for the building industry (22\%) (Silva et al., 2005; Gil, 2014). The main industrial applications of cork are reviewed with the indication of relevant references.

\section{CORK STOPPERS}

The closed cell walls of cork are responsible, not only for the impermeability to liquids and gases, but also for its high flexibility and compressibility. Thus, cork is a technically adequate material for the bottles sealing, mainly for the reserve wines, and wines need to age in the bottle (Borges and Cunha, 1985; Gil, 1998; Rosa et al., 2002; Silva et al., 2005). The production of the natural cork stoppers comprises several steps. After extraction from the tree, the cork planks are stored for, at least 6 months, to stabilize the texture and to promote the oxidation of polyphenols. Then they are boiled around $1 \mathrm{~h}$ in clean water to expand the lenticels, to make them more malleable and also to contribute to the reduction in the microflora population. To improve the cork cleanliness, the cork planks can be washed in an autoclave and after that they are dried and stored for some weeks, at controlled temperature and relative humidity, to stabilize. Depending on the quality (structural defects and porosity) and on the thickness, the planks are ranked in up to seven categories (Borges and Cunha, 1985; Pereira et al., 1994). Natural stoppers are punched from the best planks manually or automatically. The remaining material resulting from extraction will be used then for the production of agglomerate stoppers, disks, or other types of cork agglomerates (Borges and Cunha, 1985; Gil, 1998; Silva et al., 2005) (Figure 4). Each produced stopper is cut to size, polished, and graded but, to increase the seal properties, the axis of stopper should be parallel to the prism axis of the cork cells (Gibson and Ashby, 1997; Valverde et al., 2000). The obtained cylindrical cork stoppers are then washed in an aqueous

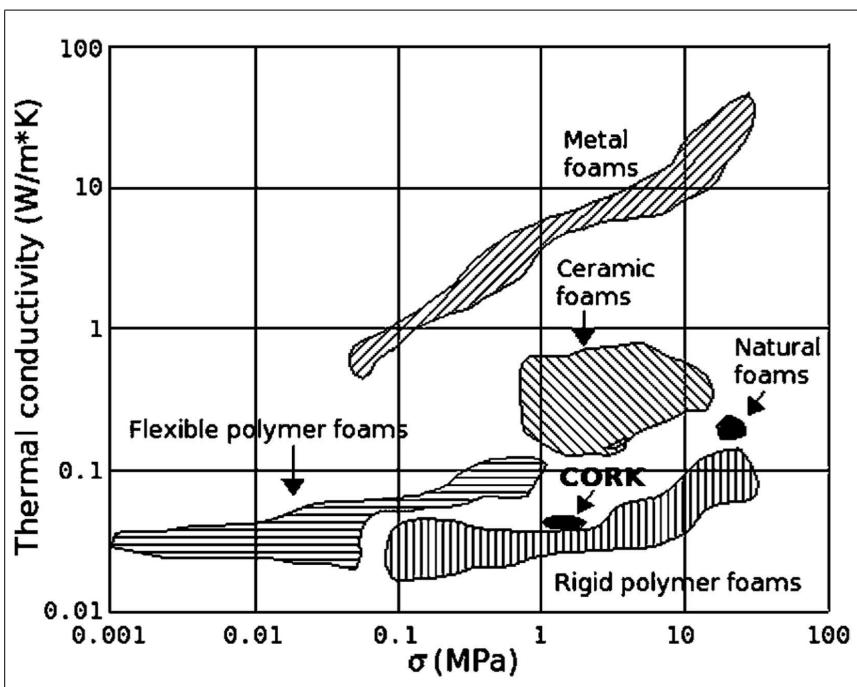

FIGURE 3 | Comparison between thermal conductivity and compressive strength $(\sigma)$ for cork and different foamed materials (Silva et al., 2005) 

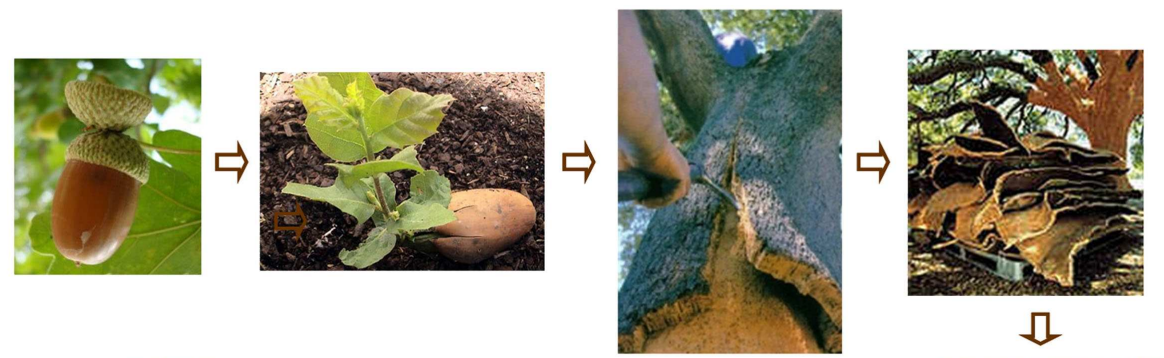

ㄱ.

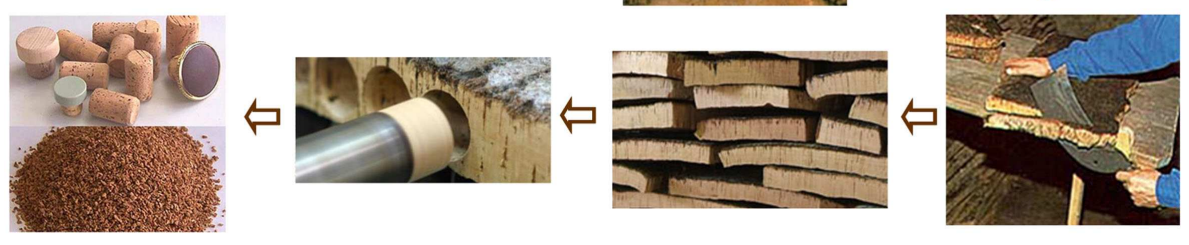

FIGURE 4 | From the cork oak (Quercus suber L.) to natural cork stoppers and cork granulates

solution of hydrogen peroxide, applying an ozone disinfection or a microwave technique, all methods to avoid contaminations and, consequently, unpleasant aromas that could change the wine's organoleptic properties (Puerto, 1990; Jens, 1999, 2002).

Finally, the stoppers are dried in special stoves until the relative moisture has been lowered and stabilized to maximize its performance in application and minimize the microbial contamination because, while eliminates the internal moisture of cork without changing its cellular structure, the drying process provides a barrier to the microorganisms entrance. Before the storage, the cork stoppers are selected, printed, and submitted to a quality control where parameters such as humidity, size/density, tightness for liquids and gases, and microbial contaminations are studied (Silva et al., 2005).

To assure a smooth and easy removal from the bottle neck, a final treatment with food grade paraffin wax and/or silicone is applied on the surface of cork stoppers.

After counted automatically and sterilized with sulfur dioxide gas, the cork stoppers are sealed in appropriate gas-barrier bags.

Actually, there are several synthetic materials available on market used as bottle stoppers such as, screw caps and synthetic stoppers that, in comparison with cork stoppers, are easier to produce, cheaper, and that avoid wine contamination with cork components. However, they present important drawbacks, such as the potential release of toxic compounds during the storage in the case of the polymeric stoppers or the metal ions, in the case of the aluminum caps (Silva et al., 2005). Thus, for the referred reasons, the cork stoppers are still widely used with success for this application.

\section{COMPOSITE MATERIALS}

Cork-based composites are made from two or more materials with very different chemical and physical properties. They maintain the properties of pure cork and, at the same time, the presence of another material allows making it more suitable for a specific use.

\section{Cork agglomerates for decorative and general uses}

The cork composites are prepared using cork granulates with different granulometry, usually between 0.5 and $30 \mathrm{~mm}$. The used granulates are often by-products derived from the natural stoppers production (Cork: a versatile material employed in many different sectors). To make cork composites, the granules are mixed with a polymeric binder and compressed under heat and pressure (Silva et al., 2005) or with a reactive prepolymer at room temperature.

The size and the proportion of cork granules (as high as 90 $\mathrm{wt} \%$ ) and the type of the binder (PU, phenol-formaldehyde resins, etc.) used in the agglomerates production process depends on the intended properties and final application (Cork: a versatile material employed in many different sectors). The obtained cork blocks are laminated, shaped to final dimensions, and finished for, later on produce general purpose agglomerates to gifts, panels, memo boards, shoe soles (Christian, 2003), between other articles (Figure 5).

Agglomerates for wall (Denisselle and Doubrovsky, 1992), and floor coverings are made in similar way, but are produced using a different binder or changing the pressure to obtain a sniffer and stronger material. To increase the wear resistance can be also employed a protective polymeric layer used alone or in multilayer products (Hajime, 2001).

Other important class of cork composites is the "rubbercork" that results from the mixture of cork granules with a rubber formulation, which is then compounded, vulcanized, shaped, and finished. The obtained composites are used as gaskets (Hiroaki, 1997) for automobiles and oil containers because, besides being impervious to liquids, do not suffer from excessive lateral expansion as result of the low Poisson ratio of cork (Fortes and Nogueira, 1989).

\section{Cork agglomerates for heat and sound insulation}

Cork is known by presenting low thermal conductivity, low speed sound propagation and low acoustic impedance, and properties that makes it appropriate to be used in applications related with the heat and sound insulation. The cork composites applied for the referred applications result from the mixture of 90-95 wt $\%$ of cork with a PU formulation and are treated at about $100^{\circ} \mathrm{C}$, during different times, to agglomerate the various components.

The resultant material is largely used in civil construction as insulating material but it is also applied as thermal and 


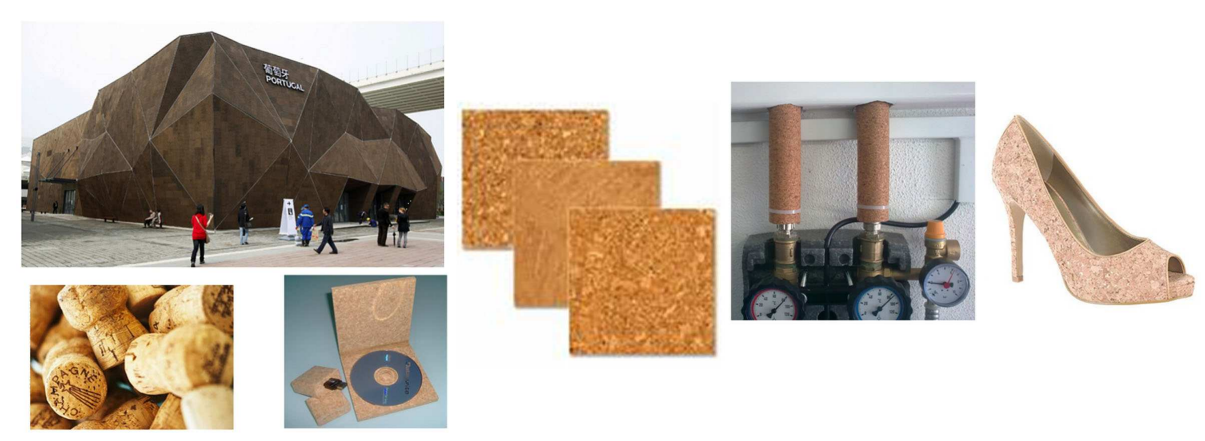

FIGURE 5 | Examples of applications for cork agglomerates.

anti-vibration shields in spacecrafts, both by ESA and NASA (Cork: a versatile material employed in many different sectors).

The cork application in spacecrafts and rockets began with the Apollo 11 mission that took the man to the moon for first time. Due to the good performance achieved, cork has also been used to other programmers as Titan, Delta, Altantis, and Ariane 5 (Skills and technology combined).

The quality of the insulation materials used in a rocket or spacecraft plays an important role in the success of the launch and operation because when they launched into space and also when return to Earth, its structure is subjected to high temperatures risking to burnt up. For the exposed reasons, cork is usually applied to critical components for the spacecraft's safety, such as the nose cone and other parts of the propulsion rockets coupled to the spacecraft (Skills and technology combined).

For insulation applications, in addition to the referred agglomerates, are also employed black agglomerates that are produced with cork granules inside a closed autoclave at high temperature (around $300^{\circ} \mathrm{C}$ ) and pressure (approximately $40 \mathrm{kPa}$ ), but without adhesives (Pereira and Ferreira, 1989; Baptista and Vaz, 1993). The agglomeration of natural cork results from the thermochemical degradation of the cork cell wall, acting as the resultant degradation by-products, mainly suberin, as natural adhesives between granules to form the corkboard (Pereira, 1992).

Among others, this material has the advantage of being reusable and a wholly natural material, without any chemical additives (Silva et al., 2005).

\section{TRANSPORTS INDUSTRY}

The very low density of cork $\left(0.24 \mathrm{~g} / \mathrm{cm}^{3}\right)$ combined with the good insulation properties makes it very attractive to the transport industry, where it is used to make some part of vehicles, such as trains, cars, and buses. Due to the presented elasticity, cork shows an appropriate performance to be applied in gaskets and sealing parts of cars (Cork: a versatile material employed in many different sectors).

\section{EMERGENT APPLICATIONS}

Cork is usually related with wine stoppers and agglomerates to decoration and thermal and acoustic insulation. Although the referred material has physical, chemical, and mechanical properties, which give great potential for new applications that will be briefly described in this topic.

\section{Sorption applications}

The residues from the cork companies, mainly cork powder, are generally considered waste and used as energy source, but recently its use as sorbent of contaminants has gained relevance due to its low costs combined with an adequate performance (Chubar et al., 2004a; Silva et al., 2005). Despite usually the adsorptive removal of heavy metals in waste waters is made using expensive and nonregenerable materials, such as activated alumina, activated carbon, or polymer resins, some studies (Villaescusa et al., 2000; Fiol et al., 2003; Chubar et al., 2004b) have reported the advantages of cork for the sorption of some types of heavy metals. Thus, the sorption of contaminants by sorbents of natural origin, such as cork (biosorption), due to the high cost effectiveness and environmental protection legislation, appears to be an emergent technology (Volesky, 2001).

\section{Activated carbon}

Some preliminary studies revealed that activated carbon produced from cork present adsorption properties different from other activated carbons; however, this fact coupled with the information that the micro pore volume of cork is similar to the current commercial activated carbons leads the researchers to believe that cork can be applied, with success, for novel filter applications. The microstructure and chemical composition of cork may lead to obtain activated carbons with different properties than the ones obtained from other natural and synthetic materials, such as bentonites, diatomites, or zeolites (Carrott et al., 1999; Hanzlík et al., 2004).

Recently, granules of expanded corkboard prepared from renewable biomass were used, with positive results, in the preparation of environmental friendly activated carbons to be used as adsorbents for the removal of pharmaceutical compounds, such as paracetamol, iopamidol, isoprofen, caffeine, among others (Mestre et al., 2014) (Figure 6).

\section{Pharmacological applications}

The cork industry generates large amounts of cork powder every year. Around 200 ton of cork smoker wash solids consisting in a black wax obtained in the corkboard production process is considered a residue, representing an environmental problem (Moiteiro et al., 2006). However, this residue is an advisable source of low molecular weight compounds, such as Friedelin and Friedelin derivatives that have been already studied in terms of biological 


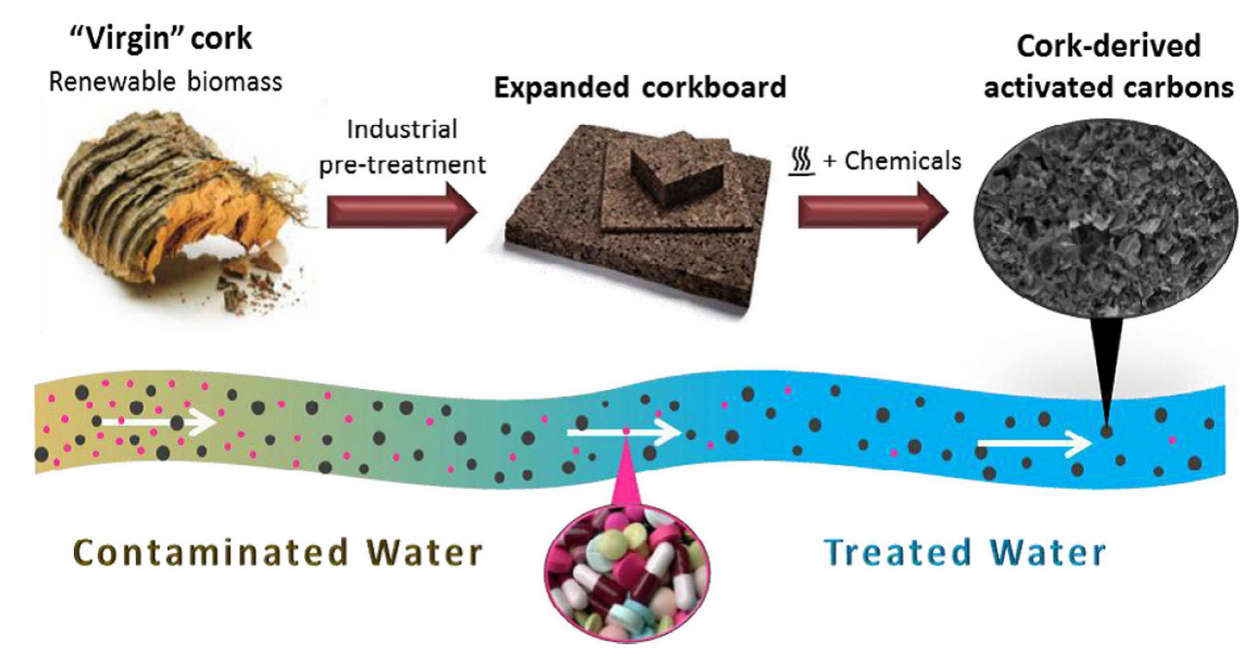

FIGURE 6 | Scheme of preparation of cork-based adsorbents for pharmaceutical compounds removal (Mestre et al., 2014).

activity (Queiroga et al., 2000; Moiteiro et al., 2001, 2004). The interest in these compounds results from their antioxidant, antistaminic, antiulcer (Moiteiro et al., 2001), anti-inflammatory (Simándi et al., 2002), and anticancer effects (Castola et al., 2005). Since triterpenoides, i.e., modified triterpenes, are known for presenting some pharmacological and pesticidal (insecticidal, phytotoxic) effects, Moiteiro et al. studied the synthesis, bioactivity screening, and the relationship between structure-activity of various synthetic triterpenoids prepared using cork processing by-products (Moiteiro et al., 2006).

Besides the referred compounds, cork also contains sterols, flavonoids, and simple phenolic compounds that are also known for biological activity. For example, sterols reduce cholesterol problems (Tapiero et al., 2003) and cancer proliferation (Block et al., 2004), while flavonoids acts as antioxidants (Rice-Evans et al., 1996) and can be used in cancer chemoprevention (Cai et al., 1997). Thus, due to components with potential health benefits (Moure et al., 2001; Silva et al., 2005), cork appears attractive for pharmaceutical industries. To notice that being less expensive than other antioxidant sources, cork can also be attractive for cosmetic, food, and plastics industries (Moure et al., 2001).

\section{Cork powder liquefaction}

The cork industry consumes around 280,000 ton/year of cork, from which around 210,000 ton/year is processed, and the remaining part is rejected, mainly as dust. The granulation of this dust generates during the milling process, large amounts of powder that should exceed 50,000 ton/year (Cordeiro et al., 1998; Silva et al., 2005; Gandini et al., 2006). So far, this powder is valorized for the production of energy by burning in furnaces, but in the future, it can play an important role in the scope of the so-called "biorefineries." This by-product can be more efficiently used with resort to liquefaction or by the extraction of some components, such as suberin, that is the major component of cork and that can also be potentially used for preparation of PUs (Cordeiro et al., 1998).
Liquefaction of cork can be performed in different ways giving rise to liquids with different compositions. The preparative chromatography allows for the separation of different fractions that can be used for different applications, such as liquid fuel and intermediate materials for the preparation of plastics, adhesives, and coatings (Evtiouguina et al., 2002; Soares et al., 2014; Yona et al., 2014).

For example, liquid ecopolyols presenting similar hydroxyl values to petroleum-based polyols can be synthesized by acid liquefaction of cork powder. The obtained polyols are then used in semi-rigid PU foam formulations (Soares et al., 2014).

\section{ENVIRONMENTAL IMPACT OF CORK}

Besides almost all cork materials can be recycled, they accumulate during the life time $\mathrm{CO}_{2}$ fixed by the cork tree, thus slowing its emission for the atmosphere. After their life time, cork materials can be incinerated producing a quantity of $\mathrm{CO}_{2}$ equivalent to the fixed one. Cork is considered a "carbon neutral" material (Gil, 2014), contributing for the increasing of $\mathrm{CO}_{2}$ fixation because the periodic extraction of cork oaks generates 250-400\% more cork that would be produced if they were not explored. It should be noted that $1.5 \mathrm{~kg}$ of $\mathrm{CO}_{2}$ is generated to produce 1000 cork stoppers, but to produce the same amount of plastic stoppers and screwcaps are generated 14 and $37 \mathrm{~kg}$ of $\mathrm{CO}_{2}$, respectively (Gil, 1998, 2014; Pereira, 2007; Corticeira Amorim, 2008).

\section{CONCLUSIONS AND PERSPECTIVES}

The origin, extraction process, structure, chemical composition, properties, environmental impact, and mostly the main applications of cork were briefly described.

This work showed that this natural composite material present a unique combination of properties, which makes it suitable for a broad spectrum of applications and for many others still under study.

The development of new cork-based composites proper to be applied in different business areas is considered one of the 
most promising fields of cork technology. Several cork composites resulting from $\mathrm{R} \& \mathrm{D}$ efforts are almost ready to be used.

\section{REFERENCES}

Baptista, A. P. M., and Vaz, M. D. C. (1993). Comparative wear testing of flooring materials. Wear 162, 990-995. doi:10.1016/0043-1648(93)90109-Y

Barberis, A., Dettori, S., and Filigheddu, M. R. (2003). Management problems in Mediterranean cork oak forests: post-fire recovery. J. Arid Environ. 54, 565-569. doi:10.1006/jare.2002.1079

Bento, M. F. S., Cunha, M. A., Moutinho, A. M. C., Pereira, H., and Fortes, M. A. (1992). A mass spectrometry study of thermal-dissociation of cork. Int. J. Mass Spectrom. 112, 191-204. doi:10.1016/0168-1176(92)80004-K

Bernards, M. A., and Lewis, N. G. (1998). The macromolecular aromatic domain in suberized tissue: a changing paradigm. Phytochemistry 47, 915-933. doi:10. 1016/S0031-9422(98)80052-6

Block, S., Baccelli, C., Tinant, B., Meervelt, L. V., Rozenberg, R., Jiwan, J.-L. H., et al. (2004). Diterpenes from the leaves of Croton zambesicus. Phytochemistry 65, 1165-1171. doi:10.1016/j.phytochem.2004.02.023

Borges, M., and Cunha, C. (1985). Boletim da Junta Nacional de Cortiça 565, 678-679.

Cai, Q., Rahn, R. O., and Zhang, R. (1997). Dietary flavonoids, quercetin, luteolin and genistein, reduce oxidative DNA damage and lipid peroxidation and quench free radicals. Cancer Lett. 119, 99-107. doi:10.1016/S0304-3835(97) 00261-9

Carrott, P. J. M., Carrott, M. M. L. R., and Lima, R. P. (1999). Preparation of activated carbon "membranes" by physical and chemical activation of cork. Carbon 37, 515-517. doi:10.1016/S0008-6223(99)00013-5

Castola, V., Marongiu, B., Bighelli, A., Floris, C., and Casanova, J. (2005). Extractives of cork (Quercus suber L.): chemical composition of dichloromethane and supercritical $\mathrm{CO}_{2}$ extracts. Ind. Crop. Prod. 21, 65-69. doi:10.1016/j.indcrop. 2003.12.007

Christian, B. (2003). Shoe Sole, EP1314370. Munich: European Patent Office.

Chubar, N., Carvalho, J. R., and Correia, M. J. N. (2004a). Heavy metals biosorption on cork biomass: effect of the pre-treatment. Colloid. Surface. A 238, 51-58. doi:10.1016/j.colsurfa.2004.01.039

Chubar, N., Carvalho, J. R., and Correia, M. J. N. (2004b). Cork biomass as biosorbent for $\mathrm{Cu}(\mathrm{II}), \mathrm{Zn}(\mathrm{II})$ and $\mathrm{Ni}(\mathrm{II})$. Colloid. Surface. A 230, 57-65. doi:10.1016/j.biortech.2008.05.050

Cordeiro, N., Belgacem, M. N., Silvestre, A. J. D., Pascoal Neto, C., and Gandini, A. (1998). Cork suberin as new source of chemicals: 1. Isolation and chemical characterisation of its composition. Int. J. Biol. Macromol. 22, 71-80. doi:10.1016/S0141-8130(97)00090-1

Cordeiro, N. M. A., Neto, C. P., Gandini, A., and Belgacem, M. N. (1995). Characterization of the cork surface by inverse gas chromatography. J. Colloid Interface Sci. 174, 246-249. doi:10.1006/jcis.1995.1387

Cork Information Bureau. (2010). Cork, culture, nature, future. Santa Maria de Lamas: Press Release.

Cork: A Versatile Material Employed in Many Different Sectors. Decoded Science. Available at: http://www.decodedscience.com/cork-a-versatile-materialemployed-in-many-different-sectors $/ 3525$

Cortiça. Available at: http://www.ctb.com.pt/?page_id=939

Corticeira Amorim. (2008). Relatório de Sustentabilidade da Corticeira Amorim SGPS S.AI. Mozelos: Corticeira Amorim.

Costa, A., Pereira, H., and Oliveira, A. (2003). Variability of radial growth in cork oak adult trees under cork production. For. Ecol. Manage. 175, 239-246. doi:10.1016/S0378-1127(02)00145-7

Denisselle, A., and Doubrovsky, G. (1992). Material in the Form of a Plate Capable of Forming a Heat-Insulating Barrier, Fire-Protection Wall Including this Material, and Casing Including Such a Wall. FR2672961. Paris: Institut National de la Propriete Industrielle.

Evtiouguina, M., Barros-Timmons, A., Cruz-Pinto, J. J., Pascoal Neto, C., Belgacem, M. N., and Gandini, A. (2002). Oxypropylation of cork and the use of the ensuing polyolsin polyurethane formulations. Biomacromolecules 3, 57-62. doi:10.1021/bm010100c

Fiol, N., Villaescusa, I., Martínez, M., Miralles, N., Poch, J., and Serarols, J. (2003). Biosorption of Cr(VI) using low cost sorbents. Environ. Chem. Lett. 1, 135-139. doi:10.1007/s10311-003-0027-6

Fortes, M. A., and Nogueira, M. T. (1989). The Poisson effect in cork. Mater. Sci. Eng. A 122, 227-232. doi:10.1016/0921-5093(89)90634-5
Fortes, M. A., and Rosa, M. E. (1988). Densidade da cortiça: factores que a influenciam. Boletim do Instituto dos Produtos Florestais - Cortiça 593, 65-68.

Gandini, A., Pascoal Neto, C., and Silvestre, A. J. D. (2006). Suberin: a promising renewable resource for novel macromolecular materials. Prog. Polym. Sci. 31, 878-892. doi:10.1016/j.progpolymsci.2006.07.004

Gibson, L. J., and Ashby, M. F. (1997). Cellular Solids: Structure and Properties, 2nd Edn. Cambridge: Cambridge University Press, 453-467.

Gibson, L. J., Easterling, K. E., and Ashby, M. F. (1981). The structure and mechanics of cork. Proc. R. Soc. Lond. A Mater. A 377, 99-117. doi:10.1098/ rspa.1981.0117

Gil, L. (1998). Cortiça: Produção, Tecnologia e Aplicacação. Lisbon: INETI.

Gil, L. (2014). Cork: a strategic material. Front Chem. 2:16. doi:10.3389/fchem.2014. 00016

Hajime, I. (2001). Wear-Resistant Flooring. JP2001047411. Tokyo: Japan Patent Office.

Hanzlík, J., Jehlicka, J., Sebek, O., Weishauptová, Z., and Machovic, V. (2004). Multicomponent adsorption of $\mathrm{Ag}(\mathrm{I}), \mathrm{Cd}(\mathrm{II})$ and $\mathrm{Cu}(\mathrm{II})$ by natural carbonaceous materials. Water Res. 38, 2178-2184. doi:10.1016/j.watres.2004.01.037

Hiroaki, A. (1997). Gasket Material Layer Including Cork, Fibers, Rubber, and a Rubber Chemical. US5615897. Arlington, VA: United States Department of Commerce: Patent and Trademark Office.

Jens, J. (1999). Treatment Method for Cork Material and Corks. CA2319351. Quebec: Canadian Intellectual Property Office.

Jens, J. (2002). Method for Manufacturing Sterilized Corks Involving Microwave Irradiation. NZ505790. Lower Hutt: Intellectual Property Office of New Zealand.

Medeiros, H. (1945). Porquê Isolamentos a Base de Cortiça? Boletim da Junta Nacional de Cortiça 76, 165-170.

Mestre, A., Pires, R. A., Aroso, I., Fernandes, E. M., Pinto, M. L., Reis, R. L., et al. (2014). Activated carbons prepared from industrial pre-treated cork: sustainable adsorbents for pharmaceutical compounds removal). Chem. Eng. J. 253, 408-417. doi:10.1016/j.cej.2014.05.051

Moiteiro, C., Justino, F., Tavares, R., Marcelo-Curto, M. J., and Florencio, M. H. (2001). Synthetic secofriedelane and friedelane derivatives as inhibitors of human lymphocyte proliferation and growth of human cancer cell lines in vitro. J. Nat. Prod. 64, 1273-1277. doi:10.1021/np010217m

Moiteiro, C., Manta, C., Justino, F., Tavares, R., Curto, M. J. M., Pedro, M., et al. (2004). Hemisynthetic secofriedelane triterpenes with inhibitory activity against the growth of human tumor cell lines in vitro. J. Nat. Prod. 67, 1193-1196. doi:10.1021/np0498915

Moiteiro, C., Marcelo-Curto, M. J., Mohamed, N., Bailén, M., Martínez-Dias, R., and González-Coloma, A. (2006). Biovalorization of friedelane triterpenes derived from cork processing industry byproducts. J. Agric. Food Chem. 54, 3566-3571. doi:10.1021/jf0531151

Mourão, P. A. M., Carrott, P. J. M., and Ribeiro Carrott, M. M. L. (2011). Potencialidades da cortiça na obtenção de carvões activados. Ciência Tecnol. Mater. 23, 26-33.

Moure, A., Cruz, J. M., Franco, D., Domínguez, J. M., Sineiro, F., Domínguez, H., et al. (2001). Natural antioxidants from residual sources. Food Chem. 72, 145-171. doi:10.1016/S0308-8146(00)00223-5

Pereira, H. (1979). Constituição química da cortiça - Estado actual dos conhecimentos. Cortiça 483, 259-264.

Pereira, H. (1982). Studies on the chemical composition of virgin and reproduction cork of Quercus suber L. An. Inst. Super. Agronom. 40, 17-25. doi:10.1016/j.jplph. 2012.08.023

Pereira, H. (1988). Chemical composition and variability of cork from Quercus suber L. Wood Sci. Technol. 22, 211-218. doi:10.1007/BF00386015

Pereira, H. (1992). Thermochemical degradation of cork. Wood Sci. Technol. 26, 259-269. doi:10.1007/BF00200161

Pereira, H. (2007). Cork: Biology, Production and Uses. Oxford: Elsevier.

Pereira, H., and Ferreira, E. (1989). Scanning electron microscopy observations of insulation cork agglomerates. Mater. Sci. Eng. A 111, 217-225. doi:10.1016/09215093(89)90215-3

Pereira, H., Melo, B., and Pinto, R. (1994). Yield and quality in the production of cork stoppers. Holz als Roh und Werstoff. 52, 211-214. doi:10.1007/ BF02619093

Puerto, R. J.-J. (1990). Process for Washing Cork Stoppers. FR2639282. Paris: Institut National de la Propriete Industrielle.

Queiroga, C. L., Silva, G. F., Dias, P. C., Possenti, A., and Carvalho, J. E. (2000). Evaluation of the antiulcerogenic activity of friedelan $3 \beta$-ol and friedelin 
isolated from Maytenus ilicifolia (Celastraceae). J. Ethnopharmacol. 72, 465-468. doi:10.1016/S0378-8741(00)00237-3

Rice-Evans, C. A., Miller, N. J., and Paganga, G. (1996). Structure-antioxidant activity relationships of flavonoids and phenolic acids. Free Radic. Biol. Med. 20, 933-956. doi:10.1016/0891-5849(95)02227-9

Rosa, M. E., and Fortes, M. A. (1991). Deformation and fracture of cork in tension. J. Mater. Sci. 26, 341-348. doi:10.1007/BF00576525

Rosa, M. E., Fortes, M. A., and Nunez, R. V. (2002). Cork and plastic stoppers. Key Eng. Mater. 230-232, 295-299. doi:10.1002/jssc.201100871

Rosa, M. E., and Pereira, H. (1994). Heat treatment of cork. Holzforschung 48, 226-232. doi:10.1515/hfsg.1994.48.3.226

Rosa, M. E., Pereira, H., and Fortes, M. A. (1990). Effects of hot water treatment on the structure and properties of cork. Wood Fiber Sci. 22, 149-164.

Silva, S. P., Sabino, M. A., Fernandes, E. M., Correlo, V. M., Boesel, L. F., and Reis, R. L. (2005). Cork: properties, capabilities and applications. Int. Mater. Rev. 50, 345-365. doi:10.1179/174328005X41168

Simándi, B., Kristo, S. T., Kéry, Á, Selmeczi, L. K., Kmecz, I., and Kemény, S. (2002). Supercritical fluid extraction of dandelion leaves. J. Supercrit. Fluid 23, 135-142. doi:10.1016/S0896-8446(02)00012-8

Skills and Technology Combined. Available at: http://www.amorim.com/en/ for-your-business/Aerospace/39/

Soares, B., Gama, N., Freire, C., Barros-Timmons, A., Brandão, I., Silva, R., et al. (2014). Ecopolyol production from industrial cork powder via acid liquefaction using polyhydric alcohols. ACS Sustain. Chem. Eng. 2, 846-854. doi: $10.1021 / \mathrm{sc} 400488 \mathrm{c}$

Tapiero, H., Townsend, D. M., and Tew, K. D. (2003). Phytosterols in the prevention of human pathologies. Biomed. Pharmacother. 57, 321-325. doi:10.1016/S07533322(03)00104-5

The Many Uses of Cork. Available at: http://darkside.hubpages.com/hub/cork

Valverde, J. M., Carrillo, J. F. D., Sinencio, E. S., and Valverde, R. P.-A. (2000). Method for sorting cork stoppers. ES2140309. Madrid: Oficina Española de Patentes y Marcas.
Vaz, M. F., and Fortes, M. A. (1998). Friction properties of cork. J. Mater. Sci. 33, 2087-2093. doi:10.1023/A:1004315118535

Villaescusa, I., Martinez, M., and Miralles, N. (2000). Heavy metal uptake from aqueous solution by cork and yohimbe bark wastes. J. Chem. Technol. Biotechnol. 75, 812-816. doi:10.1002/1097-4660(200009)75:9<812::AID-JCTB284>3. $0 . \mathrm{CO} ; 2-\mathrm{B}$

Volesky, B. (2001). Detoxification of metal-bearing effluents: biosorption for the next century. Hydrometallurgy 59, 203-216. doi:10.1016/S0304-386X(00) 00160-2

Yona, A. M. C., Budija, F., Kricej, B., Kutnar, A., Pavlic, M., Pori, P., et al. (2014). Production of biomaterials from cork: liquefaction in polyhydricalcohols at moderate temperatures. Ind. Crops Prod. 54, 296-301. doi:10.1016/j.indcrop. 2014.01.027

Conflict of Interest Statement: The authors declare that the research was conducted in the absence of any commercial or financial relationships that could be construed as a potential conflict of interest.

Received: 22 August 2014; accepted: 05 January 2015; published online: 02 February 2015.

Citation: Duarte AP and Bordado JC (2015) Cork - a renewable raw material: forecast of industrial potential and development priorities. Front. Mater. 2:2. doi: 10.3389/fmats.2015.00002

This article was submitted to Composite Materials, a section of the journal Frontiers in Materials.

Copyright $(2015$ Duarte and Bordado. This is an open-access article distributed under the terms of the Creative Commons Attribution License (CC BY). The use, distribution or reproduction in other forums is permitted, provided the original author (s) or licensor are credited and that the original publication in this journal is cited, in accordance with accepted academic practice. No use, distribution or reproduction is permitted which does not comply with these terms. 